\title{
Acute stress may induce ovulation in women
}

\author{
Juan J Tarín*1, Toshio Hamatani² and Antonio Cano ${ }^{3}$
}

\begin{abstract}
Background: This study aims to gather information either supporting or rejecting the hypothesis that acute stress may induce ovulation in women. The formulation of this hypothesis is based on 2 facts: 1) estrogen-primed postmenopausal or ovariectomized women display an adrenal-progesterone-induced ovulatory-like luteinizing hormone (LH) surge in response to exogenous adrenocorticotropic hormone (ACTH) administration; and 2) women display multiple follicular waves during an interovulatory interval, and likely during pregnancy and lactation. Thus, acute stress may induce ovulation in women displaying appropriate serum levels of estradiol and one or more follicles large enough to respond to a non-midcycle LH surge.

Methods: A literature search using the PubMed database was performed to identify articles up to January 2010 focusing mainly on women as well as on rats and rhesus monkeys as animal models of interaction between the hypothalamic-pituitary-adrenal (HPA) and hypothalamic-pituitary-gonadal (HPG) axes.
\end{abstract}

Results: Whereas the HPA axis exhibits positive responses in practically all phases of the ovarian cycle, acute-stressinduced release of LH is found under relatively high plasma levels of estradiol. However, there are studies suggesting that several types of acute stress may exert different effects on pituitary LH release and the steroid environment may modulate in a different way (inhibiting or stimulating) the pattern of response of the HPG axis elicited by acute stressors.

Conclusion: Women may be induced to ovulate at any point of the menstrual cycle or even during periods of amenorrhea associated with pregnancy and lactation if exposed to an appropriate acute stressor under a right estradiol environment.

\section{Background}

It is known that the percentage of pregnancies resulting from single episodes of forced penile-vaginal intercourse (rape) is significantly higher $(8.0 \%$ in a sample of 405 women from a national random-digit dialing sample of households in USA) than the percentage of pregnancies resulting from single episodes of consensual, unprotected intercourse (3.1\% in a sample of 221 women with no fertility problems planning to become pregnant in USA) [1]. It is worth mentioning that data from the study by Gottschall and Gottschall [1] were adjusted for the use of oral contraception and intra-uterine devices (IUDs). Furthermore, Gottschall and Gottschall [1] elegantly ruled out the possibility that in their study higher rape-pregnancy rates may result from (1) women being more likely to report to medical or law-enforcement authorities rapes

* Correspondence: tarinjj@uv.es

1 Department of Functional Biology and Physical Anthropology, Faculty of Biological Sciences, University of Valencia, Burjassot, Valencia 46100, Spain Full list of author information is available at the end of the article resulting in conception; (2) women sometimes attributing paternity to rapists when they were fertilized by a consensual partner; and (3) a high number of rape victims coming from the most fecund age cohorts of the population, i.e. rapists disproportionately would target young women in their most fecund years. These points were the main grounds used in previous studies to reject the fact that per-incident rape-pregnancy risk had been reiteratively reported to be higher than per-incident consensual pregnancy risk.

It is also known that, in fertile women planning to become pregnant, ovulation and conception may occur on any day of the menstrual cycle, although the maximum probability is reached at the middle of the cycle [2]. Furthermore, ovulations and conceptions may arise during periods of amenorrhea associated with oral contraceptive use, drug addiction, pregnancy (superfetation; for review, see Pape et al. [3]) and lactation. In addition, fertilization of $\geq 2$ oocytes from the same menstrual cycle by 
sperm from separate acts of sexual intercourse has been also reported (superfecundation [4,5]).

All this epidemiological evidence, together with the fact that copulation can trigger or hasten (facilitate) ovulation in otherwise spontaneous ovulating species such as the rat (for reviews, see Gibson et al. [6], Milligan [7], Bakker and Baum [8] and Nagy et al. [9]), led Zarrow et al. [10] and Jöchle $[11,12]$ to propose that women may be facultative coitus-induced ovulators.

This attractive and stimulating hypothesis is supported by the fact that $68 \%$ of women display 2 follicular waves and the remaining $32 \%$ exhibit 3 waves of ovarian follicular development during an interovulatory interval [13]. It is likely that women exhibit waves of follicular development during pregnancy and lactation as it occurs in cattle, sheep, goats and mares [14] (for review, see Evans [15]).

The presence of multiple follicular waves in women may provide an extra source of oocytes to be ovulated if an appropriate non-midcycle luteinizing hormone $(\mathrm{LH})$ surge took place. We should note that follicular waves can be either ovulatory (the final wave of follicular development) or anovulatory (all the preceding waves) $[13,16]$. Twenty one percent of the anovulatory follicular waves are major, i.e. those in which one follicle is selected to be dominant over other follicles of the wave, and the remaining $79 \%$ minor, i.e. those in which no selection of a dominant follicle is evidenced. Although, anovulatory follicles do not develop as large as ovulatory follicles, they grow to an ostensible preovulatory diameter before undergoing atresia (maximum diameter of the dominant follicle of an anovulatory major wave: $12.9 \pm 0.8 \mathrm{~mm}$, range $10-17 \mathrm{~mm}$; maximum diameter of the largest follicle of an anovulatory minor wave: $8.1 \pm 0.1 \mathrm{~mm}$, range $7-9 \mathrm{~mm}$ ) [17]. The maximum diameters reached by dominant follicles from anovulatory major waves (range 10-17 $\mathrm{mm}$ ) are compatible with potential ovulations if follicles are correctly stimulated. In fact, spontaneous ovulations in normal menstrual cycles have been reported to occur in follicles $\geq 15 \mathrm{~mm}$ in diameter [16].

Despite the fact that women display multiple waves of follicular development during an interovulatory interval, and likely during pregnancy and lactation, the hypothesis that women may be coitus-induced ovulators is directly refuted by studies showing that neither coitus nor orgasm induces a surge in LH secretion (and thus ovulation) in women [18-20] and rhesus monkeys [21]. Results from these classical studies have been recently endorsed by Baerwald et al. $[13,16]$. These authors tracked daily the follicle diameter and follicle number present in the ovaries of 50 healthy women of reproductive age $(28.0 \pm 6.9$, range 19-43 years) displaying clinically normal menstrual cycles and not taking medications known to interfere with reproductive function. The ovarian ultrasono- graphic examinations only evidenced ovulations in follicles from the last wave of the interovulatory cycle, which emerges at the early follicular phase. The preceding waves, emerging at the luteal phase, were anovulatory in all 50 women entered into the study. This fact contradicts the assumption that coitus may induce ovulation in women. We should bear in mind that, in addition to a periovulatory peak, human beings display no changes at all or even rises in male- and female-initiated sexual activity, woman's sexual desire, autosexual activity and sexual arousability, and interpersonal sexual activities, including sexual intercourse, during the mid-follicular and late-luteal phases (for review, see Tarín and GómezPiquer [22]). Thus, it is expected that a non-negligible number of the 50 women analyzed by Baerwald et al. $[13,16]$ was presumably engaged in sexual intercourse during the period of ultrasonographic evaluations (one interovulatory cycle).

If we consider the laboratory rat as a paradigm of facultative coitus-induced ovulation, it can be noted that there are notable differences between women and rats in the neuroendocrine mechanisms controlling the ovarian cycle. For instance, in contrast to women, both spontaneous and induced ovulatory mechanisms are integrated in the rat. Female rats have no functional corpora lutea and must receive vulval, vaginal and/or cervical intromissive stimulation in order for the ovaries to develop fully functional corpora lutea. Mating stimulates the release of prolactin from the anterior pituitary, which is required for activation of the corpora lutea and progesterone biosynthesis (for review, see Bakker and Baum [8]). Furthermore, although technical difficulties have precluded determining the ovarian dynamics in rats by transcutaneous ultrasound bio-microscopy [23], it is expected that rats exhibit a single wave of follicular development such as evidenced in the mouse [23] and the coitus-induced ovulating species analyzed as of today, including cats, llamas and camels (for review, see Evans [15]).

\section{Interaction of the hypothalamic-pituitary-adrenal (HPA) and hypothalamic-pituitary-gonadal (HPG) axes}

While the woman's reproductive physiology does not fit the rat paradigm of facultative coitus-induced ovulation, the HPA and HPG axes interact with each other in a similar way in both species. Indeed, in rats and women, there is a positive coupling between the HPA axis and the HPG axis at the time of the preovulatory LH surge. In women, initiation of the LH surge takes place either at 04.00 a.m. in $20 \%$ of the cases or at $08.00 \mathrm{a}$.m. in the remaining $80 \%$ of the cases. The onset of the LH surge is strongly coupled with the time at which the peak (acrophase) of the cortisol circadian rhythm occurs, i.e. maximal cortisol plasma concentrations take place at $04.00 \mathrm{a} . \mathrm{m}$. when the LH preovulatory surge initiates at $04.00 \mathrm{a} . \mathrm{m}$. and at 08.00 
a.m. when the LH preovulatory surge starts at 08.00 a.m. [24]. Likewise, in the laboratory rat, both the preovulatory LH surge and the maximal plasma values of the corticosterone circadian rhythm are observed during the transition from the light to the dark phase $(2 \mathrm{~h}$ preceding and $2 \mathrm{~h}$ following) on the day of proestrus $[25,26]$.

Moreover, it is well-known that prolonged or chronic stress in rats and women may block, inhibit or delay the preovulatory LH surge and therefore disrupt the estrous or menstrual cycle (for reviews, see Rivier and Rivest [27] and Kalantaridou et al. [28]). On the contrary, women and rats exposed to acute stress may respond with an adrenal-progesterone-induced LH surge (for review, see Mahesh and Brann [29]).

There is considerable evidence in rats and women showing an elevation in the levels of serum progesterone mainly from the adrenal glands prior to the onset of the LH surge. This increase in progesterone levels serves to initiate, synchronize, potentiate and limit the preovulatory LH surge to a single day (for review, see Mahesh and Brann [29]). In order for progesterone to exert its facilitatory role on gonadotropin secretion, the presence of a background of high estradiol is essential [30]. This is due to the fact that estradiol induces the expression of anterior pituitary, hypothalamic and extrahypothalamic progesterone receptors, which function as transcriptional regulators that prompt alterations in gene expression needed for facilitation of neurosecretion of gonadotropin-releasing hormone (GnRH) surges and release of periovulatory gonadotropin surges (for reviews, see Mahesh and Brann [29] and Levine et al. [31]).

It is not surprising, therefore, that progesterone and natural mineralocorticoids, such as deoxycorticosterone, and synthetic glucocorticoids, such as triamcinolone acetonide, which possess "progestin-like" activity, stimulate the release of $\mathrm{LH}$ and follicle-stimulating hormone (FSH) when administered acutely to pregnant mare serum gonadotropin (PMSG)-primed immature [32] or estrogen-primed ovariectomized immature rats [33]. In estrogen-treated menopausal women, it has been demonstrated that progesterone administration is able to induce a pre-ovulatory-type surge of LH and FSH (for review, see Mahesh and Brann [29]. These findings have led to propose that the improvement in menstrual rhythm and ovulatory activity following glucocorticoid therapy in women suffering from polycystic ovarian syndrome or other syndromes of androgen excess may be due to its direct effects on the release of gonadotropins, in addition to the ability of glucocorticoids to suppress adrenal overproduction of androgens [32,33].

Moreover, it has been reported that a single injection of adrenocorticotropic hormone (ACTH) to estrogenprimed intact and ovariectomized immature rats causes a significant elevation in serum LH and FSH levels. How- ever, this ACTH treatment fails to induce a surge of gonadotropins in non-estrogen-primed intact immature rats. It is worth mentioning that of the 2 major adrenal steroids secreted as result of ACTH administration, i.e. progesterone and corticosterone, only progesterone is able to stimulate LH release in estrogen-primed ovariectomized immature rats on the day of its administration [34]. Likewise, a 3-h intravenous infusion of ACTH to postmenopausal or ovariectomized women with estrogen replacement raises the plasma levels of corticosterone and progesterone 3-4 $\mathrm{h}$ after injection, accompanied by a significant stimulation of $\mathrm{LH}$ release $2-3 \mathrm{~h}$ after the initial raise in progesterone [35].

\section{Aim of the study}

The aim of this bioessay is to gather information either supporting or rejecting the hypothesis that acute stress may induce ovulation in women. The formulation of this hypothesis is based on 2 facts: 1) estrogen-primed postmenopausal or ovariectomized women display an adrenal-progesterone-induced ovulatory-like $\mathrm{LH}$ surge in response to exogenous $\mathrm{ACTH}$ administration; and 2) women display multiple follicular waves during an interovulatory interval, and likely during pregnancy and lactation. Thus, acute stress may induce ovulation in women displaying appropriate serum levels of estradiol and one or more follicles large enough to respond to a non-midcycle LH surge.

\section{Methods}

As the HPA and HPG axes interact with each other in a similar way in rats and women, a literature search using the PubMed database [36] was performed to identify all the articles up to January 2010 dealing with the response of the HPA and HPG axes to acute stressors in rats and women. Studies on rhesus monkeys (Macaca mulatta) and previous reviews were also consulted. The following key words were used: "acute stress", "gonadotropin secretion", "luteinizing hormone surge", "hypothalamic-pituitary-adrenal axis", "hypothalamic-pituitary-gonadal axis", "premature luteinization" and "adrenal progesterone secretion".

\section{Changes in serum levels of estradiol during the ovarian cycle in rats and women}

As the serum concentration of estradiol in rats and women fluctuates during the estrous or menstrual cycle, it is expected that the LH-release response of the anterior pituitary to an acute-stress-induced surge of adrenal progesterone will vary during the estrous or menstrual cycle. Thus, in order to analyze the studies reviewed in this bioessay, it is important to recall the pattern of fluctuations in serum levels of estradiol during the ovarian cycle in both rats and women (female macaque monkeys have a 
pattern of estradiol variation similar to women [37]). In particular, in Fischer 344 rats, serum levels of estradiol display one single cycle of increasing and decreasing levels during the 4- or 5-day estrous cycles. Serum concentration of estradiol shows a single peak of $\approx 257 \mathrm{pmol} / \mathrm{L}$ on the morning of proestrus, preceding the zenith of the LH surge $(\approx 0.076 \mathrm{IU} / \mathrm{L})$ that arises during the transition from the light to the dark phase. The peak of estradiol is followed by a nadir of $\approx 55 \mathrm{pmol} / \mathrm{L}$ on the night of proestrus, with this baseline level being kept during estrus and diestrus-1. Finally, on the morning of diestrus2 , estradiol levels start to rise, reaching a level of $\approx 165$ $\mathrm{pmol} / \mathrm{L}$ on the night of diestrus- 2 , and a level of $\approx 239$ $\mathrm{pmol} / \mathrm{L}$ on the night of diestrus-3 in 5-day cyclers [26].

On the other hand, in women, serum concentration of estradiol shows 2 cycles of increasing and decreasing levels. Serum baseline levels of 147-165 pmol/L estradiol start to increase $\approx 5$ or 6 days before the preovulatory peak of LH in women with 3 or 2 follicular waves, respectively. It reaches a maximum level of $\approx 808 \mathrm{pmol} / \mathrm{L} 1$ day before the preovulatory peak of $\mathrm{LH}(\approx 26 \mathrm{IU} / \mathrm{L})$ in women with 2 follicular waves, or coinciding with the peak of $\mathrm{LH}$ $(\approx 35 \mathrm{IU} / \mathrm{L})$ in women with 3 follicular waves. After reaching this maximum, serum levels of estradiol drop to the baseline level of 147-165 pmol/L on day 3 after ovulation but elevate thereafter to $\approx 367 \mathrm{pmol} / \mathrm{L}$ for a week in women with 2 or 3 follicular waves, although women with 3 follicular waves exhibit more fluctuating values. At the end of the luteal phase, serum concentration of estradiol drops to the baseline level of 147-165 pmol/L, with this level being kept steady during the early follicular phase [13].

\section{HPA axis response to acute stress Effect of ovarian cycle}

Table 1 shows the effect of ovarian cycle on HPA axis response to acute stress in rats, rhesus monkeys and women.

\section{Rats}

In rats with 5-day estrous cycles, the surgical stress of laparotomy on the morning of proestrus leads to release of adrenal estradiol and progesterone preceding an early surge of LH from the pituitary [38]. Moreover, intact 4and 5-day cycling rats exhibit increased HPA sensitivity, releasing higher amounts of $\mathrm{ACTH}$ and corticosterone into the blood stream, immediately after a 20-min restraint on the morning of proestrus than animals at either estrus or diestrus (combined diestrus-1, 2 and 3) [39]. Notwithstanding, Carey et al. [40] found higher plasma levels of ACTH and corticosterone immediately after a 20-min restraint in 4-day cycling rats but did not evidence a significant effect of the estrous cycle on plasma concentrations of these hormones

\section{Non-human primates}

In cycling female rhesus monkeys, a 30-min intracerebroventricular administration of interleukin- $1 \alpha$, which simulates an inflammatory/immune-like challenge, induces a higher increase in plasma levels of cortisol and progesterone if administered during the mid-follicular phase compared to the early-follicular phase [41].

\section{Women}

Women with normal cycles undergoing bilateral ovariectomy plus total hysterectomy under general anesthesia during the mid- to late-follicular phase of the menstrual cycle respond with a small increase in plasma levels of progesterone $12 \mathrm{~h}$ after surgery preceding a small rise of LH. Likewise, after the surgical stress of cholecystectomy for benign conditions of the gallbladder under general anesthesia during the early- to mid-follicular phase, women exhibit a small surge-like increase in plasma levels of progesterone $12 \mathrm{~h}$ after the operation [42]. These increases, however, are not observed in women undergoing bilateral ovariectomy plus total hysterectomy during the early- to mid-luteal phase $[42,43]$.

Other studies show that women in the mid-luteal phase of the menstrual cycle display enhanced plasma levels of ACTH in response to a 20 -min progressive treadmill exercise compared to women in the early follicular phase [44]. Mid-luteal phase women also display reduced sensitivity to glucocorticoid feedback (lower suppression of plasma cortisol in response to a low dose of synthetic glucocorticoid dexamethasone) and decreased glucocorticoid receptor (type II) mRNA expression in lymphocytes compared to women in the early follicular phase [45]. In addition, the cortisol response to a 90-min submaximal bicycle [46] or treadmill [47] exercise is higher in the mid-luteal phase than in the early-follicular [47], mid-follicular [46] and late-follicular phases [47]. Likewise, a lower adrenocortical reactivity (decreased plasma cortisol levels) to the psychological stress of self-evaluation has been evidenced during the ovulatory period (between 12-16 days from the onset of the previous menstruation) than during the premenstrual phase (between 1-3 days prior to the onset of the next menstruation) [48]. There are, however, other studies that either do not find menstrual cycle-related differences in the HPA axis responsivity to intense and moderate physical exercise [49-51] or to the psychological stress of remembering stressful situations in their lives and self-evaluation [52]. Interestingly, although Galliven et al. [51] did not find a significant effect of the menstrual cycle on plasma cortisol levels after a 20-min progressive submaximal treadmill, the analysis of the net integrated area under the curve revealed a marginal $(\mathrm{P}=0.056)$ lower response of cortisol in the periovulatory (between 10-16 days after the start of menses) phase compared with the early-mid-follicular (between 3-9 days after the start of menses) and mid-late- 
Table 1: Effect of ovarian cycle on HPA axis response to acute stress.

\begin{tabular}{|c|c|c|c|c|}
\hline Species & Stressor & Phase of the cycle & HPA axis response & References \\
\hline \multirow[t]{3}{*}{ Rats } & Surgery & On the morning of proestrus & Positive & [38] \\
\hline & 20-min restraint & $\begin{array}{l}\text { On the morning of proestrus vs } \\
\text { either estrus or diestrus }\end{array}$ & Increased & [39] \\
\hline & & Proestrus, estrus and diestrus II & No cycle effect & {$[40]$} \\
\hline Rhesus monkeys & $\begin{array}{l}\text { 30-min intracerebroventricular } \\
\text { administration of interleukin-1a }\end{array}$ & $\begin{array}{l}\text { Mid-follicular vs early-follicular } \\
\text { phase }\end{array}$ & Increased & [41] \\
\hline \multirow[t]{11}{*}{ Women } & $\begin{array}{l}\text { Bilateral ovariectomy plus total } \\
\text { hysterectomy }\end{array}$ & Mid- to late-follicular phase & Positive & [43] \\
\hline & & Early- to mid-luteal phase & No response & {$[42,43]$} \\
\hline & Cholecystectomy & Early- to mid-follicular phase & Positive & {$[42]$} \\
\hline & $\begin{array}{l}\text { 20-min progressive submaximal } \\
\text { treadmill exercise }\end{array}$ & $\begin{array}{l}\text { Mid-luteal phase vs early } \\
\text { follicular phase }\end{array}$ & Increased & {$[44]$} \\
\hline & $\begin{array}{l}\text { 90-min submaximal bicycle } \\
\text { exercise }\end{array}$ & $\begin{array}{l}\text { Mid-luteal phase vs mid-follicular } \\
\text { phase }\end{array}$ & Increased & {$[46]$} \\
\hline & $\begin{array}{l}\text { 90-min submaximal treadmill } \\
\text { exercise }\end{array}$ & $\begin{array}{l}\text { Mid-luteal phase vs early- and } \\
\text { late-follicular phase }\end{array}$ & Increased & [47] \\
\hline & $\begin{array}{l}\text { 60-min progressive submaximal } \\
\text { treadmill exercise }\end{array}$ & Mid-follicular and luteal phase & No cycle effect & [49] \\
\hline & $\begin{array}{l}\text { Progressive maximal treadmill } \\
\text { exercise to voluntary exhaustion } \\
\text { or } 40 \text {-min submaximal treadmill } \\
\text { exercise }\end{array}$ & $\begin{array}{l}\text { Early-follicular vs mid-luteal } \\
\text { phase }\end{array}$ & No cycle effect & {$[50]$} \\
\hline & $\begin{array}{l}20 \text {-min progressive submaximal } \\
\text { aerobic treadmill }\end{array}$ & $\begin{array}{l}\text { Early-mid-follicular, } \\
\text { periovulatory and mid-late luteal } \\
\text { phase }\end{array}$ & No cycle effect & [51] \\
\hline & $\begin{array}{l}\text { Psychological stress of } \\
\text { remembering stressful situations } \\
\text { in their lives and self-evaluation }\end{array}$ & $\begin{array}{l}\text { Menstrual and periovulatory } \\
\text { (late-follicular, ovulatory and } \\
\text { early-luteal phases) phase }\end{array}$ & No cycle effect & {$[52]$} \\
\hline & $\begin{array}{l}\text { Psychological stress of } \\
\text { self-evaluation }\end{array}$ & $\begin{array}{l}\text { Ovulatory period vs } \\
\text { premenstrual phase }\end{array}$ & Decreased & [48] \\
\hline
\end{tabular}

luteal (between 18-26 days after the start of menses) phases.

\section{Concluding remarks}

From the studies analyzed in this section, it seems that the ovarian cycle modulates the HPA axis response to acute stressors. In rats, it appears that proestrus morning is the more sensitive period. In rhesus monkeys, the HPA axis response is higher during the mid-follicular phase than during the early-follicular phase. And in women, the period more responsive seems to be during the mid-follicular and mid- and late-luteal phases. The absence of effect of the menstrual cycle on HPA axis responsivity to physical stress found in several studies may be explained by the presence of uncontrolled variables related to the training status of women and possibly to the training regimen followed in the days previous to the exercise test (cited by Williams et al. [53]).

\section{Effect of hormone treatment}

Table 2 shows the effect of hormone treatment on HPA axis response to acute stress in rats, rhesus monkeys and women.

\section{Rats}

It is known that immediately after exposure of ovariectomized rats to a 20-min restraint stress the plasma levels of ACTH are higher in estradiol-treated rats compared to the oil-treated control and to estradiol plus progesteronetreated rats. Moreover, during the 20-min period of restraint, the plasma levels of $\mathrm{ACTH}$ and corticosterone are always higher in the estradiol-treated group than in the oil-treated control and estradiol plus progesteronetreated rats [39]. Likewise, during the first $60 \mathrm{~min}$ after exposure to stress from a novel environment, ovariectomized estradiol- and estradiol plus progesterone-treated rats display an enhanced $\mathrm{ACTH}$ response compared to ovariectomized non-treated control and progesteronetreated rats. Ovariectomized estradiol plus progesterone- 
Table 2: Effect of hormone treatment on HPA axis response to acute stress.

\begin{tabular}{|c|c|c|c|c|}
\hline Species & Stressor & Hormone treatment & HPA axis response & References \\
\hline \multirow[t]{4}{*}{ Rats } & 20-min restraint & $\begin{array}{l}\text { Estradiol vs oil and estradiol } \\
\text { plus progesterone }\end{array}$ & Increased & [39] \\
\hline & $\begin{array}{l}\text { Exposition to a novel } \\
\text { environment }\end{array}$ & $\begin{array}{l}\text { Estradiol and estradiol plus } \\
\text { progesterone vs no hormone } \\
\text { treatment and progesterone }\end{array}$ & Increased & {$[40]$} \\
\hline & 5 -sec footshock & $\begin{array}{l}\text { Estradiol vs no hormone } \\
\text { treatment }\end{array}$ & Increased & {$[54]$} \\
\hline & $\begin{array}{l}1 \text {-min exposure to ether } \\
\text { vapors }\end{array}$ & $\begin{array}{l}\text { Estradiol vs no hormone } \\
\text { treatment }\end{array}$ & Increased & {$[54]$} \\
\hline \multirow[t]{3}{*}{ Rhesus monkeys } & $\begin{array}{l}\text { 30-min } \\
\text { intracerebroventricular } \\
\text { infusion of interleukin-1a }\end{array}$ & $\begin{array}{l}\text { Estradiol at doses resulting in } \\
\text { the typical high levels of } \\
\text { plasma estradiol that } \\
\text { reproduce the late follicular } \\
\text { phase }\end{array}$ & Increased & {$[56]$} \\
\hline & & $\begin{array}{l}\text { Estradiol at doses resulting in } \\
\text { low levels of plasma estradiol }\end{array}$ & Increased & {$[57]$} \\
\hline & & $\begin{array}{l}\text { Estradiol at doses that results } \\
\text { in intermediate levels of } \\
\text { plasma estradiol that } \\
\text { reproduce the early-mid } \\
\text { follicular phase }\end{array}$ & Inhibited & [57] \\
\hline \multirow[t]{4}{*}{ Women } & $\begin{array}{l}\text { Single intravenous injection of } \\
\text { endotoxin }\end{array}$ & $\begin{array}{l}\text { Estradiol vs no hormone } \\
\text { treatment }\end{array}$ & No treatment effect & [35] \\
\hline & $\begin{array}{l}\text { Psychological stress (speech } \\
\text { and math tasks) }\end{array}$ & $\begin{array}{l}\text { Estrogens or estrogens plus } \\
\text { progestogen vs no hormone } \\
\text { treatment }\end{array}$ & No treatment effect & {$[58]$} \\
\hline & & $\begin{array}{l}\text { Estradiol vs the same women } \\
\text { before treatment }\end{array}$ & Decreased & [59] \\
\hline & $\begin{array}{l}\text { Psychological stress (mental } \\
\text { arithmetic tasks accompanied } \\
\text { by a repetitive annoying } \\
\text { background noise }\end{array}$ & Estradiol vs placebo & Decreased & {$[60]$} \\
\hline
\end{tabular}

treated rats also display a higher corticosterone response than non-treated control and progesterone-treated rats during the same period of time [40].

Plasma levels of ACTH and corticosterone during the 2 $\mathrm{h}$ after a 5-sec footshock are higher in ovariectomized estradiol-treated rats than in ovariectomized non-treated control rats. At $20 \mathrm{~min}$ after 1-min exposure to ether vapors, plasma concentration of corticosterone is also higher in the group of estradiol-treated rats. Moreover, the $\mathrm{ACTH}$ and corticosterone secretory responses are less effectively suppressed by RU 28362 (a specific glucocorticoid receptor agonist) in estradiol-treated animals than in non-treated control rats [54]. This finding endorses other studies showing an inhibitory effect of estradiol on glucocorticoid receptor-mediated negative feedback [55].

\section{Non-human primates}

Studies in ovariectomized estrogen-replaced rhesus monkeys show that $\mathrm{ACTH}$, cortisol and progesterone responses to a 30-min intracerebroventricular infusion of interleukin- $1 \alpha$ are increased compared to the responses found in ovariectomized estrogen-replaced control monkeys infused intracerebroventricularly with a physiological saline solution. Experimental females received estrogen replacement therapy during 5 days at doses that elevated plasma estradiol concentration to $378 \mathrm{pmol} / \mathrm{L}$ (level that reproduces the typical high estradiol concentrations of the late follicular phase) [56]. The cortisol response to this immune-inflammatory challenge is also increased in ovariectomized 5-day-estrogen-treated monkeys with plasma concentrations of estradiol $\leq 73$ $\mathrm{pmol} / \mathrm{L}$ [57]. However, in 5-day-replaced rhesus monkeys with plasma levels of $114 \mathrm{pmol} / \mathrm{L}$ estradiol (concentration similar to that of the early-mid follicular phase), the cortisol response is inhibited [57].

\section{Women}

Studies in estrogen-replaced menopausal or ovariectomized women provide intriguing results. Some reports 
evidence no effect of estradiol treatment on (1) the increases of plasma cortisol and progesterone observed in response to a single intravenous injection of endotoxin after 4 weeks of treatment [mean ( \pm SEM) plasma estradiol levels: $23.5 \pm 3.3 \mathrm{pmol} / \mathrm{L}$ in unreplaced women and $315.7 \pm 36.7 \mathrm{pmol} / \mathrm{L}$ after estradiol replacement] [35]; or (2) the cortisol response to psychological stressors (speech and math tasks) after at least 2 years of estrogen alone (a mixture of 6 estrogenic substances) or estrogen and progestogen treatment (authors did not specify the plasma levels of estradiol of replaced and unreplaced women) [58]. Another study shows no changes in plasma ACTH concentration or even decreased peak levels of plasma cortisol and androstenedione in response to psychological stressors (speech and math tasks) after 6 weeks of treatment with estradiol compared to the increases evidenced in these women before estradiol replacement (plasma estradiol levels: $\leq 73.4 \mathrm{pmol} / \mathrm{L}$ before estradiol replacement and $587.4 \pm 58.7 \mathrm{pmol} / \mathrm{L}$ after estradiol replacement) [59]. In perimenopausal women (within 2 years of their last period and actively experiencing vasomotor symptoms of menopause), estradiol supplementation for 8 weeks results in decreased plasma levels of ACTH and cortisol after a psychological stress (mental arithmetic tasks accompanied by a repetitive annoying background noise to induce difficulty in concentration) compared to placebo-treated perimenopausal women (plasma estradiol levels: $115.0 \pm 19.0 \mathrm{pmol} / \mathrm{L}$ in placebotreated women and $1118.0 \pm 111.0 \mathrm{pmol} / \mathrm{L}$ in estradioltreated women) [60].

As far as we know, there are no studies reporting increases in HPA axis reactivity to acute stressors in estrogen-treated perimenopausal, menopausal or ovariectomized women. Only one study in young men has found increased peak ACTH and cortisol responses to a brief psychosocial stress (free speech and mental arithmetic in front of an audience) after 24-48 h of estradiol treatment compared to a placebo group [61].

\section{Concluding remarks}

The studies focused on the effects of hormone replacement on HPA axis response suggest that estrogen treatment in ovariectomized females or perimenopausal and menopausal women may modify the HPA axis response to acute stressors. In rats, it appears that estradiol treatment increases the responsivity of the HPA axis to different acute stressors. In rhesus monkeys, the HPA axis response to a 30-min intracerebroventricular infusion of interleukin-1 $\alpha$ depends on the plasma level of estradiol after estrogen replacement. In particular, low and high plasma concentrations increase the response whereas intermediate concentrations are inhibitory. In contrast, estrogen replacement in women does not change or even may decrease the typical response of the HPA axis to acute stressors. Although it is difficult to compare among studies the absolute plasma levels of estradiol exhibited by women before being exposed to acute stressors because different measurement methods were used, it is worth mentioning that, in all the studies analyzed in this section, independently of the replacement regimen followed, the HPA axis always displayed a positive response when plasma levels of estradiol were relatively low $(\leq 73.4$ $\mathrm{pmol} / \mathrm{L})$ or intermediate $(115.0-315.7 \mathrm{pmol} / \mathrm{L})$ whereas the response was decreased when plasma levels of estradiol were relatively high (587.4-1118.0 pmol/L). Thus, it can be hypothesized that the response of the HPA axis to inflammatory or psychological stressors evidenced in perimenopausal, menopausal or ovariectomized women may depend on the range of plasma estradiol concentration present in women when exposed to these stressors.

\section{Acute-stress-induced LH release Effect of ovarian cycle}

Table 3 shows the effect of ovarian cycle on acute-stressinduced LH release in rats, rhesus monkeys and women. Rats

Brown-Grant et al. [62] reported that $\approx 50 \%$ of lightinduced persistent-vaginal-estrus rats, which show elevated levels of estradiol (similar to the levels on the morning of proestrus in rats maintained under a controlled photoperiod [63]), can ovulate when placed in a mating cage without a male or when subjected to a more severe stress such as laparotomy. The laparotomy-associated stress can also advance the time of LH surge (zenith: $\approx 0.130 \mathrm{IU} / \mathrm{L}$ ) in 5 -day cycling rats if performed on the morning of proestrus [38]. On the contrary, in 4-day cyclers, laparotomy delays pituitary LH discharge and ovulation if carried out on the morning of diestrus-2 [64]. An inhibition of the primary LH surge and ovulation has also been found in 4-day cycling rats after intracerebroventricular injection of interleukin- $1 \alpha$ or $\beta$ on the morning of proestrus [65]. Furthermore, it has been reported that a rapid blood volume depletion from the external jugular veins under constant ether anesthesia is able to increase plasma LH concentrations (from $\approx 0.017$ $\mathrm{IU} / \mathrm{L}$ to $0.043 \mathrm{IU} / \mathrm{L}$ ) during the first $10 \mathrm{~min}$ after the initial blood loss in 4-day cycling rats at diestrus (combined diestrus-1 and 2) [66].

\section{Non-human primates}

In cycling rhesus monkeys, Norman et al. [67] found that a prolonged $(6 \mathrm{~h})$ chair restraint resulted in suppression of LH release, but 1 out of the 9 females tested exhibited a 2-5-fold increase in plasma levels of LH within $30 \mathrm{~min}$ of the initiation of restraint in both the mid-follicular and mid-luteal phases, as well as an increase in frequency of LH pulses over that normally evidenced in the mid-luteal phase. Furthermore, a 30-min intracerebroventricular administration of interleukin- $1 \alpha$ induces a 3 -fold increase in LH by $5 \mathrm{~h}$ after interleukin- $1 \alpha$ infusion if administered 
Table 3: Effect of ovarian cycle on acute-stress-induced LH release.

\begin{tabular}{|c|c|c|c|c|}
\hline Species & Stressor & Phase of the cycle & LH release & References \\
\hline \multirow[t]{5}{*}{ Rats } & $\begin{array}{l}\text { Placed in a mating cage without a } \\
\text { male or laparotomy }\end{array}$ & $\begin{array}{l}\text { Persistent-vaginal-estrus } \\
\text { (estradiol levels similar to the } \\
\text { levels on the morning of } \\
\text { proestrus) }\end{array}$ & Positive (inferred by ovulation) & [63] \\
\hline & Laparotomy & On the morning of proestrus & $\begin{array}{l}\text { Advance of the time of the } \\
\text { primary LH surge }\end{array}$ & {$[38]$} \\
\hline & & On the morning of diestrus- 2 & $\begin{array}{l}\text { Delay of the time of the primary } \\
\text { LH surge (and ovulation) }\end{array}$ & {$[64]$} \\
\hline & $\begin{array}{l}\text { Intracerebroventricular injection } \\
\text { of interleukin-1a or } \beta\end{array}$ & On the morning of proestrus & $\begin{array}{l}\text { Inhibition of the primary LH surge } \\
\text { (and ovulation) }\end{array}$ & {$[65]$} \\
\hline & Rapid blood volume depletion & $\begin{array}{l}\text { At diestrus (combined diestrus-1 } \\
\text { and 2) }\end{array}$ & Positive & {$[66]$} \\
\hline \multirow[t]{3}{*}{ Rhesus monkeys } & 30-min chair restraint & $\begin{array}{l}\text { Mid-follicular and mid-luteal } \\
\text { phases }\end{array}$ & Positive & {$[67]$} \\
\hline & $\begin{array}{l}\text { 30-min intracerebroventricular } \\
\text { administration of interleukin-1a }\end{array}$ & Mid-follicular phase & Positive & {$[41]$} \\
\hline & & Early follicular phase & No release & {$[41]$} \\
\hline \multirow[t]{8}{*}{ Women } & $\begin{array}{l}\text { Bilateral ovariectomy plus total } \\
\text { hysterectomy }\end{array}$ & Mid- to late-follicular phase & Positive & {$[43]$} \\
\hline & & Early- to mid-luteal phase & No release & {$[43]$} \\
\hline & Cholecystectomy & Early- to mid-follicular & Positive & {$[42]$} \\
\hline & $\begin{array}{l}\text { Progressive submaximal treadmill } \\
\text { exercise to exhaustion }\end{array}$ & $\begin{array}{l}\text { Mid-follicular and mid-luteal } \\
\text { phase }\end{array}$ & No release & [69] \\
\hline & $\begin{array}{l}\text { 90-min submaximal bicycle } \\
\text { exercise }\end{array}$ & $\begin{array}{l}\text { Mid-follicular and mid-luteal } \\
\text { phase }\end{array}$ & Decreased plasma levels of LH & {$[46]$} \\
\hline & $\begin{array}{l}\text { 60-min progressive submaximal } \\
\text { treadmill exercise }\end{array}$ & Mid-follicular phase & Positive & [49] \\
\hline & & Mid-follicular phase & Positive & {$[53]$} \\
\hline & & Mid-luteal phase & No release & {$[70]$} \\
\hline
\end{tabular}

during the mid-follicular phase, but there is no $\mathrm{LH}$ response during the early follicular phase [41]. We should mention that 1 out of the 9 mid-follicular monkeys exhibited a sustained surge-like release of LH after interleukin$1 \alpha$ treatment reaching a maximum $(\approx 0.130 \mathrm{IU} / \mathrm{L})$ at $13 \mathrm{~h}$ after treatment [41]. These findings contrast with the inhibition of the primary LH surge in cycling rats after intracerebroventricular injection of interleukin- $1 \alpha$ or $\beta$ on the morning of proestrus (see above). Discrepancies between rhesus monkeys and rats may be explained by the higher capacity of the rat adrenal glands to synthesize and release progesterone compared to the primate adrenal glands [68]. Thus, administration of interleukin in rats may induce the release of adrenal progesterone at concentrations that become inhibitory to LH secretion, whereas in rhesus monkeys the activation of the HPA axis by interleukin administration may result in the release of adrenal progesterone at concentrations equivalent to those observed during the preovulatory midcycle rise (cited by Xiao and Ferin [68]).

\section{Women}

The surgical stress of bilateral ovariectomy plus total hysterectomy performed under general anesthesia during the mid- to late-follicular phase of the menstrual cycle induces a small increase in plasma levels of LH $36 \mathrm{~h}$ after surgery (from $\approx 6 \mathrm{IU} / \mathrm{L}$ to $8 \mathrm{IU} / \mathrm{L}$ ), preceded by an elevation of adrenal progesterone [43]. Likewise, women undergoing cholecystectomy under general anesthesia during the early- to mid-follicular phase exhibit a small but significant increase in plasma levels of $\mathrm{LH}$ (from $\approx 6$ $\mathrm{IU} / \mathrm{L}$ to $12 \mathrm{IU} / \mathrm{L}$ ) and FSH (from $\approx 6 \mathrm{IU} / \mathrm{L}$ to $9 \mathrm{IU} / \mathrm{L}$ ) $12 \mathrm{~h}$ after the operation, coinciding with a peak in plasma progesterone [42]. However, no wave-like changes in plasma LH levels are observed in women undergoing bilateral ovariectomy plus total hysterectomy during the early- to mid-luteal phase [43].

Although some studies report that light, heavy or exhaustive exercise does not alter [69] or even decreases [46] plasma levels of LH at the mid-follicular or midluteal phases, other studies evidence small increases in 
plasma levels of LH in response to acute physical exercise. In fact, 60 min of progressive submaximal treadmill exercise in the mid-follicular phase produces a small surgelike increase in plasma levels of $\mathrm{LH}$ (from $\approx 10$ to $14 \mathrm{IU} / \mathrm{L}$ ) in 24-h fasted eumenorrheic women [49] as well as a significant stimulatory effect on maximal peak amplitude of LH pulses (from 8.8 to $9.5 \mathrm{IU} / \mathrm{L}$ ) in sedentary eumenorrheic women [53]. In contrast, the same stress applied in the mid-luteal phase [70] does not affect the LH pulse characteristics.

\section{Concluding remarks}

The studies analyzed in this section show conflicting results on the effects of ovarian cycle on acute-stressinduced LH release in rats. Some studies seem to indicate that the adenohypophysis is much more responsive to acute stressors on the morning of proestrus than at diestrus. In contrast, other studies suggest the opposite. It can be hypothesized that the degree of adrenal-progesterone response depends on the strength of the stressor applied. Thus, strong stressors such as intracerebroventricular injection of interleukin- $1 \alpha$ or $\beta$ or rapid blood volume depletion may induce an adrenal-progesterone response higher than that elicited by more moderate stressors such as laparotomy. Such an adrenal-progesterone response would inhibit the release of LH if plasma levels of estradiol are elevated (proestrus morning) but it would stimulate the release of LH under low estradiol backgrounds (e.g. the diestrus stage). Likewise, a moderate rise in adrenal-progesterone concentrations equivalent to that observed during the preovulatory midcycle rise would be stimulatory if it takes place under high plasma levels of estradiol (proestrus morning) but it would be unable to elicit a release of LH under low estradiol backgrounds (e.g. the diestrus stage).
In rhesus monkeys, females at the mid-follicular and mid-luteal phases, but not at the early-follicular stage, display appropriate plasma levels of estradiol for acute stressors to induce a release of $\mathrm{LH}$.

Although there are some conflicting reports in women, it seems that the mid-follicular phase gathers more favorable conditions than the mid-luteal phase for the release LH by the adenohypophysis in response to acute stressors.

\section{Effect of hormone treatment}

Table 4 shows the effect of hormone treatment on acutestress-induced LH release in rats, rhesus monkeys and women.

\section{Rats}

In contrast to ovariectomized non-estrogen-primed rats, ovariectomized estrogen-primed rats respond with a small but significant LH peak $(\approx 0.017 \mathrm{IU} / \mathrm{L})$ either $1 \mathrm{~h}$ after the onset of a prolonged $(11 \mathrm{~h})$ immobilization [71] or $10 \mathrm{~min}$ after a short (15 $\mathrm{min})$ immobilization [71]. Likewise, ovariectomized rats treated with estradiol, progesterone and thyroxine respond with an $\mathrm{LH}$ surge (zenith: $\approx 0.052 \mathrm{IU} / \mathrm{L}$ ) $10 \mathrm{~min}$ after undergoing a rapid blood volume depletion from the external jugular veins. This response, however, is not observed in ovariectomized non-treated rats [66]. We should note, however, that acute stressors such as the transfer of rats to a novel environment followed by a return to their original quarters $30 \mathrm{~min}$ later, or 15 -min exposure to a strobe light have no effects on serum LH in 2-week ovariectomized estradiol-primed rats, but significantly enhance $\mathrm{LH}$ release (zenith: $\approx 0.015 \mathrm{IU} / \mathrm{L}$ and $\approx 0.020 \mathrm{IU} / \mathrm{L}$, respectively) in 2-week ovariectomized non-estrogen-primed rats [72].

Table 4: Effect of hormone treatment on acute-stress-induced LH release.

\begin{tabular}{|c|c|c|c|c|}
\hline Species & Stressor & Hormone treatment & LH release & References \\
\hline \multirow[t]{3}{*}{ Rats } & 1-h or 10-min immobilization & Estradiol vs no hormone treatment & Positive & {$[71,72]$} \\
\hline & Rapid blood volume depletion & $\begin{array}{l}\text { Estradiol+progesterone+thyroxinevs } \\
\text { no hormone treatment }\end{array}$ & Positive & {$[66]$} \\
\hline & $\begin{array}{l}\text { Transfer to a novel environment } \\
\text { followed by a return to the original } \\
\text { quarters } 30 \text { min later, or } 15 \text {-min } \\
\text { exposure to strobe light }\end{array}$ & No hormone treatment vs estradiol & Positive & {$[72]$} \\
\hline \multirow[t]{2}{*}{ Rhesus monkeys } & $\begin{array}{l}\text { 30-min intracerebroventricular } \\
\text { infusion of interleukin-1a }\end{array}$ & $\begin{array}{l}\text { Estradiol at doses that result in } \\
\text { plasma estradiol levels that } \\
\text { reproduce the late follicular phase }\end{array}$ & Positive & {$[56]$} \\
\hline & & $\begin{array}{l}\text { Estradiol at doses that result in } \\
\text { plasma estradiol levels that } \\
\text { reproduce the early-mid follicular } \\
\text { phase }\end{array}$ & No effect & {$[57]$} \\
\hline Women & $\begin{array}{l}\text { Single intravenous injection of } \\
\text { endotoxin }\end{array}$ & Estradiol vs no hormone treatment & Positive & [35] \\
\hline
\end{tabular}




\section{Non-human primates}

In ovariectomized rhesus monkeys after 5 days of estrogen replacement therapy at doses simulating the late follicular phase, a 30-min intracerebroventricular infusion of interleukin- $1 \alpha$ results in a small but significant increase in $\mathrm{LH}$ release during the first $5 \mathrm{~h}$ after treatment (from $0.014 \mathrm{IU} / \mathrm{L}$ to $0.019 \mathrm{IU} / \mathrm{L}$ ) [56]. However, the response of $\mathrm{LH}$ is prevented in replaced monkeys with plasma levels similar to those of the early-mid follicular phase [57].

\section{Women}

Estrogen-treated menopausal or ovariectomized women respond to an inflammatory/immune-like stress, induced by single intravenous injection of endotoxin, with an ovulatory-like LH peak (50 IU/L) $7 \mathrm{~h}$ after injection. In contrast, non-estrogen treated women do not modify their basal LH levels after endotoxin injection [35].

\section{Concluding remarks}

Studies in ovariectomized rats show paradoxical results as far as the response of the adenohypophysis to different acute stressors is concerned. Whereas 2 studies [66,71] found a stimulatory effect of estradiol replacement on acute-stress-induced LH release, Briski and Sylvester [72] evidenced that several types of acute stress exerted different effects on pituitary LH release and that the steroid environment modulated in a different way (inhibiting or stimulating) the pattern of response of the HPG axis induced by these stressors.

Literature focused on rhesus monkeys shows a stimulatory effect of estradiol replacement on acute-stressinduced LH release at doses that result in plasma estradiol levels reproducing the late follicular phase. This stimulatory effect, however, is not found after estradiol treatment at doses that result in plasma estradiol levels simulating the early-mid follicular phase.

Finally, estrogen-treated menopausal or ovariectomized women respond with a clear ovulatory-like LH peak after a single intravenous injection of endotoxin [35].

\section{Summary conclusions}

The studies reviewed in this bioessay indicate that the ovarian cycle and, in particular, the female's estradiol background modulates the response of the HPA and HPG axes to acute stressors. The pattern of response, however, differs between the HPA and HPG axes. In fact, although the highest responses of the HPA axis within the ovarian cycle are observed when females display relatively high plasma levels of estradiol (proestrus morning in rats, mid-follicular phase in rhesus monkeys and mid-follicular and mid- and late-luteal phases in women), the HPA axis exhibits positive responses in practically all phases of the ovarian cycle. In contrast, it seems that there is only one specific period of time within the ovarian cycle during which the HPG axis response is possible. In particu- lar, positive responses of the HPG axis are found under relatively high plasma levels of estradiol on the morning of proestrus in rats, during the mid-follicular and midluteal phase in rhesus monkeys and during the mid-follicular phase in women. This conclusion is endorsed by the fact that the HPG axis of estrogen-treated ovariectomized females and perimenopausal or menopausal women also exhibit a positive response to acute stressors.

Two studies $[66,72]$ in the rat show that several types of acute stress may exert different effects on pituitary LH release and that the steroid environment may modulate in a different way (inhibiting or stimulating) the pattern of response of the HPG axis induced by acute stressors. In rhesus monkeys and women, the steroid environment may also modulate in a different way the pattern of response of the HPA axis (and therefore the response of HPG axis including release of LH) elicited by acute stressors. In particular, in estrogen-treated ovariectomized females and perimenopausal or menopausal women, some ranges of plasma estradiol concentration seem to prevent whereas others allow a response of the HPA axis to acute stressors.

In women, the pattern of $\mathrm{LH}$ release elicited by acute stressors may vary from small non-ovulatory rises in plasma concentrations and/or slight changes in pulse characteristics to the typical ovulatory surge that spontaneously takes place at the middle of the menstrual cycle. As women present waves of follicular development during an interovulatory interval (and likely during pregnancy and lactation), they may be induced to ovulate at any point of the menstrual cycle or even during periods of amenorrhea associated with pregnancy and lactation if exposed to an appropriate acute stressor under a right estradiol environment. We should bear in mind that the maximum diameters (range of 10-17 $\mathrm{mm}$ ) of the dominant follicles from anovulatory major waves, which account for $21 \%$ of the anovulatory follicular waves, are compatible with potential ovulations if follicles were correctly stimulated by an ovulatory-like LH surge. Follicles large enough ( $\geq 15 \mathrm{~mm}$ of diameter) to ovulate may be found in the ovaries of all the regular-cycling women at the late-mid follicular phase (growing antral follicles from the ovulatory follicular wave). In addition, they may be present in the ovaries of women exhibiting (1) a majormajor 2 -wave pattern at the mid-luteal phase $(10 \%$ of the overall population of regular-cycling women); (2) a minor-major-major 3-wave pattern at the early-mid-follicular phase $(6 \%$ of the overall population of regularcycling women); and (3) a major-major-major 3-wave pattern at the late-mid-luteal and early-mid follicular phases $(6 \%$ of the overall population of regular-cycling women) [13]. We should note, however, that ovulation during the luteal phase or during pregnancy and lactation 
are extremely rare due to the presence of negative feedbacks that prevent the LH surge.

We should bear in mind that an acute-stress-induced surge of LH is shortly preceded by an elevation of serum progesterone from the adrenal glands. This fact suggests that such an elevation of serum progesterone may advance the secretory transformation of the endometrium resulting in embryo-endometrium asynchrony and consequently reduced chances of implantation and pregnancy if ovulation and fertilization took place. However, a recent systematic review and meta-analysis [73] has not detected detrimental effects of elevated levels of progesterone on the day of human chorionic gonadotropin (hCG) administration on the probability of clinical pregnancy in women undergoing ovarian stimulation with GnRH analogues and gonadotropins for in vitro fertilization. Although this may not be the case for women treated with GnRH antagonists (for review, see Venetis et al. [73]), we should take into account that an elevation of plasma progesterone on the day of hCG administration should be sustained in order to impair endometrial receptivity. This is not the case in estrogen-treated menopausal or ovariectomized women after being exposed to single intravenous injection of endotoxin [35]. These women display a wave-like adrenal release of progesterone. In particular, plasma progesterone concentrations rise from $\approx 0.2 \mathrm{nmol} / \mathrm{L} 1-2 \mathrm{~h}$ after injection to $\approx 5 \mathrm{nmol} / \mathrm{L}$ 4-5 $\mathrm{h}$ after injection. Thereafter, plasma levels of progesterone drop to reach their baseline levels of $\approx 0.2 \mathrm{nmol} / \mathrm{L}$ $7 \mathrm{~h}$ after injection.

\section{Competing interests}

The authors declare that they have no competing interests.

\section{Authors' contributions}

JJT has been involved in conception and design, acquisition, analysis and interpretation of data and drafting the article. TH and AC have been involved in analysis and interpretation of data, and revising the article critically for important intellectual content. All authors read and approved the final manuscript.

\section{Acknowledgements}

This study was supported by grants ISCIII2006-PI0405 and PS09/00136 from "Instituto de Salud Carlos III, Ministerio de Ciencia e Innovación", cofinanced by the "Fondo Europeo de Desarrollo Regional (FEDER). JJT would like to thank Prof. Rafael Martínez-Pardo, Department of Functional Biology and Physical Anthropology, University of Valencia, for his constant support and helpful discussions on Endocrinology issues.

\section{Author Details \\ 1Department of Functional Biology and Physical Anthropology, Faculty of Biological Sciences, University of Valencia, Burjassot, Valencia 46100, Spain, 2Department of Obstetrics and Gynecology, Keio University School of Medicine, Tokyo 160-8582, Japan and ${ }^{3}$ Department of Pediatrics, Obstetrics and Gynecology, Faculty of Medicine, University of Valencia, Valencia 46010 Spain}

Received: 31 March 2010 Accepted: 26 May 2010

Published: 26 May 2010

\section{References}

1. Gottschall JA, Gottschall TA: Are per-incident rape-pregnancy rates higher than per-incident consensual pregnancy rates? Human Nature 2003, 14:1-20.

2. Wilcox AJ, Dunson DB, Weinberg CR, Trussell J, Baird DD: Likelihood of conception with a single act of intercourse providing benchmark rates for assessment of post-coital contraceptives. Contraception 2001, 63:211-215

3. Pape O, Winer N, Paumier A, Philippe HJ, Flatrès B, Boog G: Superfetation: case report and review of the literature. J Gynecol Obstet Biol Reprod (Paris) 2008, 37:791-795.

4. Girela E, Lorente JA, Alvarez JC, Rodrigo MD, Lorente M, Villanueva E: Indisputable double paternity in dizygous twins. Fertil Steril 1997, 67:1159-1161

5. Ambach E, Parson W, Brezinka C: Superfecundation and dual paternity in a twin pregnancy ending with placental abruption. J Forensic Sci 2000, 45:181-183.

6. Gibson MJ, Wu TJ, Miller GM, Silverman AJ: What nature's knockout teaches us about $\mathrm{GnRH}$ activity hypogonadal mice and neuronal grafts. Horm Behav 1997, 31:212-220.

7. Milligan SR: Induced ovulation in mammals. Oxford Rev Reprod Biol 1982, 4:1-46.

8. Bakker J, Baum MJ: Neuroendocrine regulation of $\mathrm{GnRH}$ release in induced ovulators. Front Neuroendocrinol 2000, 21:220-262.

9. Nagy P, Juhasz J, Wernery U: Incidence of spontaneous ovulation and development of the corpus luteum in non-mated dromedary camels (Camelus dromedarius). Theriogenology 2005, 64:292-304.

10. Zarrow MX, Campbell PS, Clark JH: Pregnancy following coital-induced ovulation in a spontaneous ovulator. Science 1968, 159:329-330.

11. Jöchle W: Coitus-induced ovulation. Contraception 1973, 7:523-564.

12. Jöchle W: Current research in coitus-induced ovulation a review. J Reprod Fertil Supp/ 1975, 22:165-207.

13. Baerwald AR, Adams GP, Pierson RA: Characterization of ovarian follicular wave dynamics in women. Biol Reprod 2003, 69:1023-1031.

14. Ginther OJ, Bergfelt DR: Associations between FSH concentrations and major and minor follicular waves in pregnant mares. Theriogenology 1992, 38:807-821.

15. Evans AC: Characteristics of ovarian follicle development in domestic animals. Reprod Domest Anim 2003, 38:240-246.

16. Baerwald AR, Adams GP, Pierson RA: A new model for ovarian follicular development during the human menstrual cycle. Fertil Steril 2003, 80:116-122.

17. Ginther OJ, Gastal EL, Gastal MO, Bergfelt DR, Baerwald AR, Pierson RA: Comparative study of the dynamics of follicular waves in mares and women. Biol Reprod 2004, 71:1195-1201.

18. Stearns EL, Winter JS, Faiman C: Effects of coitus on gonadotropin, prolactin and sex steroid levels in man. J Clin Endocrinol Metab 1973 37:687-691.

19. Lee PA, Jaffe RB, Midgley AR Jr: Lack of alteration of serum gonadotropins in men and women following sexual intercourse. Am J Obstet Gynecol 1974, 120:985-987.

20. Morris NM, Udry JR, Underwood LE: A study of the relationship between coitus and the luteinizing hormone surge. Fertil Steril 1977, 28:440-442.

21. Quadri SK, Pierson C, Spies HG: Failure of copulation to affect serum prolactin, $\mathrm{LH}$, and estrogen levels in female rhesus monkeys. Proc Soc Exp Biol Med 1977, 155:247-251.

22. Tarín JJ, Gómez-Piquer V: Do women have a hidden heat period? Hum Reprod 2002, 17:2243-2248.

23. Jaiswal RS, Singh J, Adams GP: High-resolution ultrasound biomicroscopy for monitoring ovarian structures in mice. Reprod Biol Endocrinol 2009, 7:69.

24. Kerdelhué B, Brown S, Lenoir V, Queenan JT Jr, Jones GS, Scholler R, Jones HW Jr: Timing of initiation of the preovulatory luteinizing hormone surge and its relationship with the circadian cortisol rhythm in the human. Neuroendocrinology 2002, 75:158-163.

25. Atkinson HC, Waddell BJ: Circadian variation in basal plasma corticosterone and adrenocorticotropin in the rat sexual dimorphism and changes across the estrous cycle. Endocrinology 1997, 138:382-388.

26. Haim S, Shakhar G, Rossene E, Taylor AN, Ben-Eliyahu S: Serum levels of sex hormones and corticosterone throughout 4- and 5-day estrous cycles in Fischer 344 rats and their simulation in ovariectomized females. J Endocrinol Invest 2003, 26:1013-1022. 
27. Rivier C, Rivest S: Effect of stress on the activity of the hypothalamicpituitary-gonadal axis peripheral and central mechanisms. Biol Reprod 1991, 45:523-532

28. Kalantaridou SN, Makrigiannakis A, Zoumakis E, Chrousos GP: Stress and the female reproductive system. J Reprod Immunol 2004, 62:61-68.

29. Mahesh VB, Brann DW: Regulation of the preovulatory gonadotropin surge by endogenous steroids. Steroids 1998, 63:616-629.

30. Cano A, Tarín JJ: Two distinct two-step ranks of progesterone stimulation after three different levels of oestrogen priming. Effect on induction of luteinizing hormone surges in young and climacteric women. Hum Reprod 1998, 13:852-858.

31. Levine JE, Chappell PE, Schneider JS, Sleiter NC, Szabo M: Progesterone receptors as neuroendocrine integrators. Front Neuroendocrinol 2001 22:69-106.

32. Brann DW, Putnam CD, Mahesh VB: Corticosteroid regulation of gonadotropin secretion and induction of ovulation in the rat. Proc Soc Exp Biol Med 1990, 193:176-180.

33. Brann DW, Putnam CD, Mahesh VB: Corticosteroid regulation of gonadotropin and prolactin secretion in the rat. Endocrinology 1990, 126:159-166.

34. Putnam CD, Brann DW, Mahesh VB: Acute activation of the adrenocorticotropin-adrenal axis effect on gonadotropin and prolactin secretion in the female rat. Endocrinology 1991, 128:2558-2566.

35. Puder JJ, Freda PU, Goland RS, Ferin M, Wardlaw SL: Stimulatory effects of stress on gonadotropin secretion in estrogen-treated women. J Clin Endocrinol Metab 2000, 85:2184-2188.

36. PubMed.gov, U.S. National Library of Medicine, National Institutes of Health [http://www.ncbi.nlm.nih.gov/sites/entrez]

37. Ferin $\mathrm{M}$ : Neuroendocrine control of ovarian function in the primate. $J$ Reprod Fertil 1983, 69:369-81.

38. Nequin LG, Alvarez JA, Campbell CS: Alterations in steroid and gonadotropin release resulting from surgical stress during the morning of proestrus in 5-day cyclic rats. Endocrinology 1975, 97:718-724.

39. Viau V, Meaney MJ: Variations in the hypothalamic-pituitary-adrenal response to stress during the estrous cycle in the rat. Endocrinology 1991, 129:2503-2511.

40. Carey MP, Deterd CH, de Koning J, Helmerhorst F, de Kloet ER: The influence of ovarian steroids on hypothalamic-pituitary-adrenal regulation in the female rat. J Endocrinol 1995, 144:311-321.

41. Xiao E, Xia-Zhang L, Thornell D, Ferin M: Interleukin-1 stimulates luteinizing hormone release during the midfollicular phase in the rhesus monkey a novel way in which stress may influence the menstrual cycle. J Clin Endocrinol Metab 1996, 81:2136-2141.

42. Messinis IE, Milingos SD, Alexandris E, Kariotis I, Kollios G, Seferiadis K: Leptin concentrations in normal women following bilateral ovariectomy. Hum Reprod 1999, 14:913-918.

43. Alexandris E, Milingos S, Kollios G, Seferiadis K, Lolis D, Messinis IE: Changes in gonadotrophin response to gonadotrophin releasing hormone in normal women following bilateral ovariectomy. Clin Endocrinol (Oxf) 1997, 47:721-726.

44. Altemus M, Roca C, Galliven E, Romanos C, Deuster P: Increased vasopressin and adrenocorticotropin responses to stress in the midluteal phase of the menstrual cycle. J Clin Endocrinol Metab 2001, 86:2525-2530

45. Altemus M, Redwine L, Leong YM, Yoshikawa T, Yehuda R, DeteraWadleigh S, Murphy DL: Reduced sensitivity to glucocorticoid feedback and reduced glucocorticoid receptor mRNA expression in the luteal phase of the menstrual cycle. Neuropsychopharmacology 1997, 17:100-109.

46. Lavoie JM, Dionne N, Helie R, Brisson GR: Menstrual cycle phase dissociation of blood glucose homeostasis during exercise. J Appl Physiol 1987, 62:1084-1089.

47. Kanaley JA, Boileau RA, Bahr JM, Misner JE, Nelson RA: Cortisol levels during prolonged exercise the influence of menstrual phase and menstrual status. Int J Sports Med 1992, 13:332-336.

48. Marinari KT, Leshner Al, Doyle MP: Menstrual cycle status and adrenocortical reactivity to psychological stress. Psychoneuroendocrinology 1976, 1:213-218.

49. Bonen A, Haynes FJ, Watson-Wright W, Sopper MM, Pierce GN, Low MP, Graham TE: Effects of menstrual cycle on metabolic responses to exercise. J Appl Physiol 1983, 55:1506-1513.
50. De Souza MJ, Maguire MS, Maresh CM, Kraemer WJ, Rubin KR, Loucks AB: Adrenal activation and the prolactin response to exercise in eumenorrheic and amenorrheic runners. J Appl Physiol 1991, 70:2378-2387

51. Galliven EA, Singh A, Michelson D, Bina S, Gold PW, Deuster PA: Hormonal and metabolic responses to exercise across time of day and menstrual cycle phase. J App/ Physio/ 1997, 83:1822-1831.

52. Abplanalp JM, Livingston L, Rose RM, Sandwisch D: Cortisol and growth hormone responses to psychological stress during the menstrual cycle. Psychosom Med 1977, 39:158-177.

53. Williams NI, McArthur JW, Turnbull BA, Bullen BA, Skrinar GS, Beitins IZ, Besser GM, Rees LH, Gilbert I, Cramer D, Perry L, Pedoe DST: Effects of follicular phase exercise on luteinizing hormone pulse characteristics in sedentary eumenorrhoeic women. Clin Endocrinol (Oxf) 1994, 41:787-794.

54. Burgess LH, Handa RJ: Chronic estrogen-induced alterations in adrenocorticotropin and corticosterone secretion, and glucocorticoid receptor-mediated functions in female rats. Endocrinology 1992, 131:1261-1269

55. Ferrini M, Lima A, De Nicola AF: Estradiol abolishes autologous down regulation of glucocorticoid receptors in brain. Life Sci 1995 57:2403-2412

56. Xiao E, Xia L, Shanen D, Khabele D, Ferin M: Stimulatory effects of interleukin-induced activation of the hypothalamo-pituitary-adrenal axis on gonadotropin secretion in ovariectomized monkeys replaced with estradiol. Endocrinology 1994, 135:2093-2098.

57. Xia-Zhang L, Xiao E, Ferin M: A 5-day estradiol therapy, in amounts reproducing concentrations of the early-mid follicular phase, prevents the activation of the hypothalamo-pituitary-adrenal axis by interleukin-1 alpha in the ovariectomized rhesus monkey. J Neuroendocrinol 1995, 7:387-392

58. Burleson MH, Malarkey WB, Cacioppo JT, Poehlmann KM, Kiecolt-Glaser JK, Berntson GG, Glaser R: Postmenopausal hormone replacement effects on autonomic, neuroendocrine, and immune reactivity to brief psychological stressors. Psychosom Med 1998, 60:17-25.

59. Lindheim SR, Legro RS, Bernstein L, Stanczyk FZ, Vijod MA, Presser SC, Lobo RA: Behavioral stress responses in premenopausal and postmenopausal women and the effects of estrogen. Am J Obstet Gynecol 1992, 167:1831-1836.

60. Komesaroff PA, Esler MD, Sudhir K: Estrogen supplementation attenuates glucocorticoid and catecholamine responses to mental stress in perimenopausal women. J Clin Endocrinol Metab 1999, 84:606-610

61. Kirschbaum C, Schommer N, Federenko I, Gaab J, Neumann O, Oellers M Rohleder N, Untiedt A, Hanker J, Pirke KM, Hellhammer DH: Short-term estradiol treatment enhances pituitary-adrenal axis and sympathetic responses to psychosocial stress in healthy young men. J Clin Endocrinol Metab 1996, 81:3639-3643.

62. Brown-Grant K, Davidson JM, Greig F: Induced ovulation in albino rats exposed to constant light. J Endocrino/ 1973, 57:7-22.

63. Takeo Y: Influence of continuous illumination on estrous cycle of rats time course of changes in levels of gonadotropins and ovarian steroids until occurrence of persistent estrus. Neuroendocrinology 1984, 39:97-104.

64. Schwartz NB: Acute effects of ovariectomy on pituitary $\mathrm{LH}$, uterine weight, and vaginal cornification. Am J Physiol 1964, 207:1251-1259.

65. Rivier C, Vale W: Cytokines act within the brain to inhibit luteinizing hormone secretion and ovulation in the rat. Endocrinology 1990, 127:849-856.

66. Seyler LE Jr, Reichlin S: Luteinizing hormone release in the rat induced by blood volume depletion. Endocrinology 1973, 92:295-302.

67. Norman RL, McGlone J, Smith CJ: Restraint inhibits luteinizing hormone secretion in the follicular phase of the menstrual cycle in rhesus macaques. Biol Reprod 1994, 50:16-26.

68. Xiao E, Ferin M: Stress-related disturbances of the menstrual cycle. Ann Med 1997, 29:215-219.

69. Jurkowski JE, Jones NL, Walker C, Younglai EV, Sutton JR: Ovarian hormonal responses to exercise. J Appl Physio/ 1978, 44:109-114

70. McArthur JW, Gilbert I, Henery RJ, Quinn J, Perry L, Cramer D, Kirkland M, Pedoe DS, Rees LH, Besser GM, Turnbull BA: The effects of submaximal endurance exercise upon LH pulsatility. Clin Endocrinol (Oxf) 1990, 32:115-126 
71. Kam K, Park Y, Cheon M, Son GH, Kim K, Ryu K: Effects of immobilization stress on estrogen-induced surges of luteinizing hormone and prolactin in ovariectomized rats. Endocrine 2000, 12:279-287.

72. Briski KP, Sylvester PW: Effect of specific acute stressors on luteinizing hormone release in ovariectomized and ovariectomized estrogentreated female rats. Neuroendocrinology 1988, 47:194-202.

73. Venetis CA, Kolibianakis EM, Papanikolaou E, Bontis J, Devroey P, Tarlatzis $B C$ : Is progesterone elevation on the day of human chorionic gonadotrophin administration associated with the probability of pregnancy in in vitro fertilization? A systematic review and metaanalysis. Hum Reprod Update 2007, 13:343-355.

doi: $10.1186 / 1477-7827-8-53$

Cite this article as: Tarín et al., Acute stress may induce ovulation in women Reproductive Biology and Endocrinology 2010, 8:53

Submit your next manuscript to BioMed Central and take full advantage of:

- Convenient online submission

- Thorough peer review

- No space constraints or color figure charges

- Immediate publication on acceptance

- Inclusion in PubMed, CAS, Scopus and Google Scholar

- Research which is freely available for redistribution

Submit your manuscript at www.biomedcentral.com/submit
C) Biomed Central 